\title{
Differences in Mathematic Connection Abilities and Self-Efficacy between Students Given Approaches Realistic Mathematics with the Approach Inquiry at Senior High School 2 Tanjung Morawa
}

\author{
Khairina Hazrati $^{1}$, Ani Minarni ${ }^{2}$, W. Rajagukguk ${ }^{3}$ \\ ${ }^{1,2,3}$ Universitas Negeri Medan, Indonesia \\ khairinahazratifathimah@gmail.com
}

\begin{abstract}
This study aims to determine how the difference between mathematical connections and self-efficacy between students who are given a realistic mathematics approach with an inquiry approach at Senior High School 2 Tanjung Morawa. The sample used in this study was Senior High School 2 Tanjung Morawa. With the method of collecting literature study data. The method used is literature study. The results of this study indicate that the overall approach to mathematics is realistic and inquiry, each of which has advantages and disadvantages, but in this study a good approach to use in students' ability to solve math problems is the inquiry approach, because with the inquiry approach students can be more active, and have ideas in solving math problems.
\end{abstract}

\author{
Keywords \\ mathematical \\ connection ability; self \\ efficacy; realistic \\ mathematical \\ approach; inquiry \\ approach

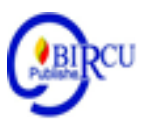

\section{Introduction}

Mathematics is the basis of science and is one of the subjects of the National Examination (UN). Mathematics with its various roles makes it a very important science, and one of the roles of mathematics is as a thinking tool to deliver students to understand the mathematical concepts they are studying. Based on its development, the problems faced in learning mathematics are increasingly complex and require a more perfect analytical structure. So in learning how to construct and create a mathematical model is needed to be a good problem solution.

Higher-order thinking skills cannot come instantly, but it requires effective and efficient management of human resources. This can be done through education (Ni'mah, Setiawan and Oktavianingtyas, 2017). In fact, many schools have low thinking ability of students. For example, students feel confused about grouping known elements in the problem, the initial steps in solving the problem, errors in performing mathematical operations, and monotony of the sample questions given by the teacher.

In an era that is completely modern and sophisticated, nowadays it is very demanding for quality human resources (HR) in all aspects. Quality human resources is a necessity that cannot be negotiated. According to Darmadi (Marliani, 2015: 15) to advance science and technology, it is necessary to have a strong understanding of mathematics from an early age. Given the importance of mathematics for the development of the world, it is very concerning if we look at the condition of students who are not very good at mathematics.

Mathematics has an important role in life, in practice some students still think of mathematics as a difficult subject. This is evident from the results of the Trends in Mathematics and Science Study (TIMSS) survey and the Program for International Student Assessment (PISA) in the following table: 
Table 1. Results of Survey Trends in Mathematics and Science Study (TIMSS)

\begin{tabular}{|l|l|l|}
\hline \multicolumn{1}{|c|}{ Year } & \multicolumn{1}{|c|}{ Rating } & \multicolumn{1}{c|}{ Score } \\
\hline 1999 & $\begin{array}{l}34 \text { from 38 } \\
\text { Country }\end{array}$ & 403 \\
\hline 2003 & $\begin{array}{l}35 \text { from 46 } \\
\text { Country }\end{array}$ & 411 \\
\hline 2007 & $\begin{array}{l}36 \text { from 49 } \\
\text { Country }\end{array}$ & 397 \\
\hline 2011 & $\begin{array}{l}38 \text { from 42 } \\
\text { Country }\end{array}$ & 386 \\
\hline 2015 & $\begin{array}{l}46 \text { from 51 } \\
\text { Country }\end{array}$ & 397 \\
\hline
\end{tabular}

Table 2. Results of the Survey Program for International Student Assessment (PISA)

\begin{tabular}{|l|l|l|}
\hline Year & Rating & Score \\
\hline 2000 & $\begin{array}{l}39 \text { from 41 } \\
\text { Country }\end{array}$ & 367 \\
\hline 2003 & $\begin{array}{l}38 \text { from 40 } \\
\text { Country }\end{array}$ & 360 \\
\hline 2006 & $\begin{array}{l}50 \text { from 57 } \\
\text { Negara }\end{array}$ & 397 \\
\hline 2009 & $\begin{array}{l}61 \text { from 65 } \\
\text { Country }\end{array}$ & 371 \\
\hline 2012 & $\begin{array}{l}64 \text { from 65 } \\
\text { Country }\end{array}$ & 375 \\
\hline 2015 & $\begin{array}{l}69 \text { from 76 } \\
\text { Country }\end{array}$ & 386 \\
\hline
\end{tabular}

Table 1 and Table 2 show that although the scores obtained by Indonesian students fluctuate from year to year, the rankings are always almost the last in the world. (PPPPTK Featured News, 2015). This shows that Indonesian students still find mathematics difficult.

This makes the basis for the importance of mathematics being taught at all levels of education. This is because, through mathematics students are trained to be skilled in solving problems in everyday life related to mathematical calculations. Mathematics can also train students in developing students' mathematical abilities, for example the ability to think logically, creatively, critically, carefully, effectively, problem solving, representation, connection, communication and so on. This is confirmed by Hendriana and Soemarmo (2014) who state that "... everyone in their life activities will be involved with mathematics, starting from simple and routine forms to very complex ones. In line with what Cokroff expressed (Abdurrahman, 2009: 253), he stated that:

"Mathematics needs to be taught to students because (1) it is always used in all aspects of life; (2) all fields of study require appropriate mathematical skills; (3) is a strong, concise and clear means of communication; (4) can be used to present information in a 
variety of ways; (5) improve logical thinking skills, accuracy, and spatial awareness; and (6) provide satisfaction with the effort to solve challenging problem. Based on this thought, a study entitled "the difference in mathematical connection ability and self-efficacy between students who are given a realistic mathematics approach with an inquiry approach in SMA Negeri 2 Tanjung Morawa.

\section{Review of Literatures}

\subsection{Mathematical Connection Capability}

Mathematics learning formulated by the National Council of Teachers of Matematics (NCTM, 2000) emphasizes that students must learn mathematics through understanding and actively build new knowledge from previous experiences and knowledge. There are five standard processes in learning mathematics, one of which is learning to link ideas (mathematical connections). Mathematical connection aims to help students see mathematical ideas as related to one another. As argued by Arlianti (2010), mathematical connections require students to be able to understand the existence of internal mathematical relationships including relationships between topics in mathematics itself, while external relationships include relationships between mathematics and other subjects and relationships with everyday life.

Without a mathematical connection, children must learn and remember too many isolated skills and concepts instead of recognizing general principles that are relevant from multiple areas of knowledge. When daily math ideas are connected to their experiences, both inside and outside of school, children will become aware of the uses and benefits of mathematics. This is in accordance with NCTM (in Arlianti, 2010) which states that through mathematical connections, students' knowledge will be expanded, students will see mathematics as a complete unit not as stand-alone material, and students will realize the usefulness and benefits of mathematics both in school. and outside of school. Thus, students do not only rely on one mathematical concept or material being studied, but indirectly students acquire a variety of different concepts / areas of knowledge, both in mathematics and outside mathematics. So it is very important that students can make connections between these knowledge ideas, which in turn will improve the quality of student learning outcomes.

The ability of a person to relate between topics in mathematics, to associate mathematics with other sciences, and with life is called the ability of mathematical connections. In accordance with the opinion of Mikovch and Monroe (in Ruspiani, 2000), 'In mathematics, at least three kinds of connections are particularly beneficial: connections within mathematics, across the curriculum, and with real word contexts.'

\subsection{Self Efficacy}

According to Bandura (1997) self-efficacy is a form of trust that a person has in their respective abilities to improve their life achievements. Self-efficacy can be in the form of how a person feels, how to think, self-motivation, and the desire to have something. Selfefficacy in social cognitive theory is a central construct that a person has.

Self-efficacy refers to the belief or perception that a person is able to organize and take the actions needed to be successful when given a task. Students who have low self-efficacy are more likely to give up in doing academic activities than students with high self-efficacy. The level of a student's self-efficacy is influenced by his success or failure in the past which will then have an impact on his success or failure in the future. 


\subsection{Self-Efficacy Function}

Self-efficacy that has been formed will affect and give function to individual activities. Bandura (1994) describes these effects and functions, namely:

\section{a. Cognitive Function}

In carrying out academic tasks, individuals set behavioral goals and objectives so that individuals can formulate appropriate actions to achieve these goals. This personal goal setting is influenced by the individual's assessment of his cognitive abilities. Cognitive function allows individuals to predict everyday events that will have repercussions in the future. The assumption that arises in this cognitive aspect is that the more effective an individual's ability is in analysis and in practicing expressing personal ideas or ideas, it will support individuals to act appropriately to achieve the expected goals. Individuals will predict events and develop ways to control events that affect their lives. This skill requires effective cognitive processing of various kinds of information.

\section{b. Motivation Function}

Individual motivation arises through optimistic thinking from within him to realize the expected goals. Individuals try to motivate themselves by establishing confidence in the actions to be carried out, planning actions that will be realized. There are several kinds of cognitive motivation that are built from several theories, namely causal attributions that come from attribution theory and expectation of results formed from the value-expectation theory. Self-efficacy affects causal attributions, where individuals who have high academic selfefficacy rate their failure to do academic tasks due to a lack of effort, while individuals with low self-efficacy rate their failure due to a lack of ability.

Expectation value theory views that motivation is governed by the expectation of the outcome (outcome expectation) and the outcome value. Outcome expectation is an estimate that certain behavior or actions will cause special consequences for individuals. It contains beliefs about the extent to which certain behaviors will have certain consequences. Outcome value is a value which means the consequences that occur when a behavior is carried out. Individuals must have high outcome values to support the outcome expectation.

\section{c. Affection Function}

Affection occurs naturally in individuals and plays a role in determining the intensity of emotional experiences. Affection is aimed at controlling anxiety and depressive feelings that get in the way of proper thought patterns to achieve goals. Affection function is related to the ability to cope with emotions that arise in oneself to achieve expected goals. An individual's belief in his abilities affects the level of stress and depression experienced when facing a difficult or threatening task. Individuals who believe that they can control threats will not generate disturbing thought patterns. Individuals who do not believe in their abilities will experience anxiety because they are unable to manage these threats.

\section{d. Selection Function}

The selection function is related to the individual's ability to select the appropriate behavior and environment, so as to achieve the expected goals. The inability of individuals to make behavioral selections makes individuals insecure, confused, and easily gives up when facing problems or difficult situations. Self-efficacy can shape an individual's life through choosing the type of activity and environment. Individuals will be able to carry out 
challenging activities and choose situations they believe they can handle. Individuals will maintain competence, interests, social relationships on the choice made.

From this description, it can be concluded that the self-efficacy process includes the cognitive process, the motivation process, the affection process, and the selection process.

\subsection{Realistic Mathematical Approach}

The new paradigm of education today places more emphasis on students as humans who have the potential to learn and develop. This new paradigm demands that teachers are no longer as sources of information but as study partners. Students are seen as active beings and have the ability to build their own knowledge. Through this new paradigm, it is hoped that in the classroom students will be active in learning, active in discussions, dare to convey ideas and accept ideas from others and have high self-confidence. To support the learning process in accordance with the changes and objectives of mathematics education, it is necessary to develop mathematics subject matter that is focused on applications in everyday life (contextual). In addition, it must be adjusted to the cognitive level of students, as well as the use of integrated evaluation methods in the learning process not only in the form of tests at the end of learning.

Judging from the new educational paradigm, the realistic mathematics approach is one of the learning approaches that are appropriate to these changes. The Realistic Mathematical Approach (PMR) was first introduced and developed in the Netherlands in 1970 by a group of mathematicians from the Freudenthal Institute, Uterecht University in the Netherlands. This approach is based on Freudenthal's concept which argues that mathematics is a human activity. The main idea is that students should be given the opportunity to reinvent mathematical ideas and concepts with adult guidance.

\subsection{The Inquiry Approach}

Inquiry which in English means inquiry, or examination, investigation. Sanjaya (2006: 194) Inquiry learning model is a series of learning activities that emphasize critical thinking processes and analysis to find and find answers to a question in question. Gulo (Trianto, 2007: 135) Inquiry strategy means a series of learning activities that involve maximally the entire ability of students to search and investigate systematically, critically, logically, analytically, so that they can formulate their own findings with confidence.

\section{Research Method}

\subsection{Types of Research}

In writing this thesis the researcher used the Library Research research method. The point is a literature study. This type of research is used by the author to obtain theoretical data as a basis for scientific theory, namely by selecting and analyzing literature relevant to the title to be studied. According to Muhamad Nazir, literature study is a data collection technique by conducting study studies of books, literature journals, notes and reports that have a relationship with the problem to be solved. according to Danial Endang AR. Literature study is research conducted by researchers by collecting a number of books, journals, magazines, leaflets, which are related to the problem and research objectives. Books and journals are used as a source of data to be processed and analyzed as has been done by many historians, literature and language experts.

Based on the above understanding, it can be concluded that the literature study method is research carried out by researchers by examining and analyzing books, journals, literature, magazines, notes and reports regarding the problem to be studied by means of books., 
literature, magazines, notes, and reports are used as data sources to be processed and analyzed.

\subsection{Object of Research}

This research is devoted to Senior High School 2 Tanjung Morawa which is located on Jl. Pendidikan, Limau Manis, Tj. Morawa, Deli Serdang Regency, North Sumatra 20362

\section{Discussion}

4.1 Description of the Difference in the Ability of Mathematical Connection and Self Efficacy between Students Given a Realistic Mathematical Approach with an Inquiry Approach According to Experts' Understanding

The main emphasis in the inquiry-based learning process lies in the ability of students to understand, then identify carefully and thoroughly, then end with providing answers or solutions to the problems presented. The main purpose of inquiry learning is to help students develop higher order thinking skills by asking motivational questions, getting answers based on curiosity, and being able to conclude and give meaning to their findings (Sadia, 2014: 124).

Inkuri learning aims to help foster motivation and enthusiasm for students in thinking because students are satisfied with the results of their own efforts through the thought process. In addition, inquiry-based learning aims to encourage students to be more courageous and creative in their imagination. With imagination, students are guided to create discoveries, both in the form of refinement of what already exists, or creating ideas, ideas, or tools that have never existed before. Therefore, students are encouraged not only to understand the subject matter, but also to be able to create an invention. In other words, students will no longer be in a telling science learning environment but will be encouraged to do science.

4.2 Description of the Difference in the Ability of Mathematical Connection and Self Efficacy between Students Given a Realistic Mathematical Approach with an Inquiry Approach According to the Journal

Research with the title difference in mathematical connection ability and self-efficacy between students who are given a realistic mathematical approach with an inquiry approach has been carried out by several previous researchers who have been poured into journals, this can help researchers to find out the difference between realistic mathematical approaches and the inquiry approach that was carried out. Previous researchers serve as a reference for current open studies.

Several previous studies that have conducted research with the same title have obtained different results, such as one of the leading researchers. According to Nursiddik, Noto and Hartono (2017), in the results of this study there is an effect of using realistic mathematics learning on students' mathematical understanding abilities in $7^{\text {th }}$ grade of Junior High School 14 Cirebon. This can be seen in the results of students' mathematical understanding abilities who use realistic mathematics learning which is higher than the mathematical comprehension abilities of students who use conventional learning. The self-confidence of seventh grade students of Junior High School 14 Cirebon City towards learning realistic mathematics which is applied to the rectangular flat shape material is a strong criterion. This means that realistic mathematics learning provides strong self-confidence in students in learning activities. This is indicated by the average percentage of the 20 students' self-confidence questionnaire scale of $66.58 \%$. From this study we see the results that the ikuiri approach has increased students 
'confidence in solving a math problem, then according to research According to Hendrik, Ani Minarni (2017) has conducted research at Sinar Husni High School with the results showing that the increase in students' conceptual understanding and self-efficacy skills who were given Discovery Learning significantly better than students who were given the conventional approach. In addition, there is a difference in the increase in the ability to understand the concept between high, medium, and low for students who are given Discovery Learning, where because there is no difference in the increase in students' Self Efficacy.

Badjeber and Fatimah (2016) the improvement of the mathematical connection ability of students who received the Alberta model of inquiry learning was significantly better than students who received conventional learning. Alberta model of inquiry learning can be used as a learning model that can be used to improve students 'mathematical connection skills, the results of this study also state that students who get an inquiry learning approach are better than students who get conventional learning, the inquiry approach can improve students' mathematical connection skills.

From the explanation above, we can see that the two approaches have their respective weaknesses and weaknesses, this is a lesson for teachers in choosing an approach that will be used in the teaching and learning process, but overall the inquiry approach is better used, because it has more advantages.

\section{Conclusion}

This study aims to determine differences in mathematical connection abilities and selfefficacy between students who are given a realistic mathematical approach with an inquiry approach. Based on the research results, the following conclusions can be drawn:

1. The realistic mathematical approach to the inquiry approach has both advantages and disadvantages, so here it is demanded that the teacher be able to read the situation in the classroom to find out what methods are suitable to be applied in the classroom.

2. In general, seeing from the theory of experts and several previous studies, a more effective approach to be applied is the inkuri approach, this is because in the inquiry approach students are required to be active, independent in solving problems, so that students can find new ideas in researchers of mathematical problems.

\section{References}

Abdurrahman, M. (2009). Pendidikan bagi Anak Berkesulitan Belajar. Jakarta : PT.Rineka Cipta.

Anam, K. M.A. (2015). Pembelajaran Berbasis Inkuiri Metode dan Aplikasi. Yogyakarta: Pustaka Pelajar.

Andriani K.R;Atun, I \& Kurniadi, Y. (2016). Pendekatan Realistic Mathematics Education untuk Meningkatkan Kemampuan Koneksi Matematis dan Disposisi Matematis Siswa. Jurnal Pena Ilmiah: Vol. 1, No. 1 (2016).

Arcat. (2013). Meningkatkan Kemampuan Spasial dan Self-Efficacy Siswa SMP melalui Model Kooperatif STAD berbantuan Wingeom. Universitas Pendidikan Indonesia : Bandung

Arikunto, S. (2009). Prosedur Penelitian Suatu Pendekatan Praktik (Edisi Revisi). Jakarta: Rineka Cipta.

Arikunto, S. (2009). Dasar-Dasar Evaluasi Pendidikan Jakarta: Bumi Aksara

Arikunto, S. (2010). Prosedur Penelitian: Suatu Pendekatan Praktek. Jakarta: Rineka Cipta

Arikunto, S. (2011). Dasar-Dasar Evaluasi Pendidikan . Jakarta: BumiAksara 
Arikunto, S. (2015). Dasar-Dasar Evaluasi Pendidikan Edisi 2. Jakarta: Bumi Aksara

Arlianti, N. (2010). Kemampuan Koneksi Matematika Siswa, (Online), (http $/ /$ nofytaarlianti. wordpress.com, diakses 10 Oktober 2019).

Azwar, Surya, E., and Saragih, S. (2017). Development of Learning Devices Based on Contextual Teaching and Learning Model Based on the Context of Aceh Cultural to Improve Mathematical Representation and Self-Efficacy Ability of SMAN 1 Peureulak Students. Journal of Education and Practice. Vol. 8, No. 27, 186-195.

Badjeber, R and Fatimah, S. (2015). Peningkatan Kemampuan Koneksi Matematis Siswa SMP melalui Pembelajaran Inkuiri Model Alberta. DOI: http://dx.doi.org/10.18269/jpmipa.v20i1.557. Jurnal Pengajaran MIPA, Volume 20, Nomor 1, April 2015, hlm. 18-26.

Bandura, A. \& Locke, E. A. (2003). Negative Self-Efficacy and Goal Effects Revisited. Journal of Applied Psychology.Vol. 88, No. 1, 87-99.

Bandura, A. (1986). Social Foundations OH Thought and Action: a Social Cognitive Theory. New Jersey: Prentice Hall

Bandura, A. (1994). Self-Efficacy. In V.S., Ramachaudran (Ed.), Encyclopedia of Human Behavior (Vol. 4, pp. 71-81). New York: Ac ademic Press.

Bandura, A. (1997). Self-Efficacy: (The Exercise of Control). New York: W. H. Freeman and Company

Bandura, A., and Schunk, D.H. (1991). Cultivating Competence, Self-Efficacy an Intrinsic Interest through Proximal Motivation. Journal of Educational Psychology, 41, 586-598.

Bell, F. H. (1978). Teaching and Learning Mathematics in Secondary School.Cetakan kedua. Dubuque, Iowa: Wm. C. Brown Company Publishers.

Budiyono.(2009). Statistika untuk Penelitian Edisi ke-2. Surakarta: Sebelas Maret University Press.

Bunga, N., Atun, I., and Julia. (2016). Pendekatan Realistic Mathematics Education untuk Meningkatkan Kemampuan Koneksi dan Komunikasi Matematis Siswa. Jurnal Pena Ilmiah: Vol. 1, No. 1 (2016).

De Lange, J. (1996). Using and Applying Mathematics in Educationan. In. A. J. Bishop. et al (Eds.) International Handbook of Mathematics Education. Kluwer, Academic Publisher. The Netherlands.

Emzir, (2011).Metodologi Penelitian Pendidikan Kuantitatif dan Kualitatif.Jakarta: PT Raja Grafindi Persada.

Fajri, H.N;Johar,R \& Ikhsan, M. (2016). Peningkatan Kemampuan Spasial dan Self-Efficacy Siswa melalui Model Discovery Learning berbasis Multimedia. VOL 9 NO 2 (2016): Beta Nopember. Doi 10.20414/Betajtm.V9i2.14. Submitted: Nov 22, 2016. Published: Dec 30, 2016

Fauzi, A. (2011). Peningkatan Kemampuan Koneksi Matematis dan Kemandirian Belajar Siswa dengan Pendekatan Pembelajaran Metakognitif di Sekolah Menengah Pertama. Disertasi S3 UPI.

Fauzi, A; Waluya, A \& Masrukan. (2019). Pembelajaran Matematika dengan Pendekatan Realistic Mathematics Education (Rme) Berbasis Soal Open-Ended untuk Meningkatkan Komunikasi Matematika. Phenomenon, Tahun 2019, Vol. 09 (No.1), pp. 87-98.Prodi Pendidikan Dasar Matematika Pasca UNNES. ISSN: 2088-7868, e-ISSN 2502-5708.

Gravemeijer. 1994. Developing Realistic Mathematics Education. Utrecht: Freudenthal Institute. http://repository.upi.edu/operator/upload/d_mat-0604957_chapter2.pdf. 
Hamdi, S. \& Abadi, A. (2014). Pengaruh Motivasi, Self-Efficacy dan Latar Belakang Pendidikan terhadap Prestasi Matematika Mahasiswa PGSD STKIP-H dan PGMI IAIH. Jurnal Riset Pendidikan Matematika. Vol. 1, No. 1, 77-87.

Harahap, A.Y.A., Surya, E \& Syahputra, E. (2018). Differences between Mathematics Representation Ability and Students' Self-Efficacy by Using Learning Cycle 7E and Discovery Learning Based on Batak Angkola Culture in SMAN 1 Sipirok. American Journal of Educational Research, 2018, Vol. 6, No.11, 1497-1504. Available Online at http://pubs.sciepub.com/education/6/11/8. OScience and Education Publishing. DOI:10.12691/education-6-11-8.

Herdian. (2010). Kemampuan Koneksi Matematika Siswa. Tersedia: (http://herdy07.wordpress.com/2010/05/27/kemampuan-koneksi matematik-siswa/).

Heryani, Y \& Setialesmana, D. (2017). Penggunaan Model Discovery Learning terhadap Peningkatkan Kemampuan Koneksi dan Komunikasi Matematik.Jurnal Pendidikan Matematika. Vol. 8, No. 1, 2017, Hal 43 - 52.

Hodgson, T.(1995). "Connections as Problem-Solving Tools", dalam Connecting Mathematics across the Curriculum. Editor: House, P.A. dan Coxford, A.F. Reston, Virginia: NCTM.

House, P. A. (1995). Connection Mathematics across the Curiculum. Yearbook Virginia: The National Council of Teachers of Mathematics, Inc.

Jauhar, M. (2011). Implementasi PAIKEM dari Behavioristik sampai Konstruktivistik. Jakarta: Prestasi Pustakaraya.

Jihad, A. (2008). Pengembangan Kurikulum Matematika (Tinjauan Teoritis dan Historis). Bandung: Multipressindo.

Liu, X \& Koirala, H. (2009). The Effect of Mathematics Self-efficacy on Mathematics Achievement of High School Students.Northeastern Educational Research Association (Nera) Confe-rence, Proceedings, 30, 1-13.

Mahanurani, I; Setiawan, T.B \& Oktavianingtyas, E. (2016). Penerapan Model Pembelajaran Kooperatif Tipe Round Table untuk Meningkatkan Aktivitas dan Hasil Belajar Siswa pada Pokok Bahasan Segitiga Kelas VII SMP Negeri 2 Pasirian Tahun Ajaran 2015/2016. CKadikma, Vol.7, No.1, hal. 57-65, April 2016.

Maisyarah, R \& Surya, E. (2017). Kemampuan Koneksi Matematis (Connecting Mathematics Ability) Siswa dalam Menyelesaikan Masalah Matematika.

Mandur, K. (2013). Kontribusi Kemampuan Koneksi, Kemampuan Representasi, dan Disposisi Matematis terhadap Prestasi Belajar Matematika Siswa SMA Swasta di Kabupaten Manggarai. Jurnal Pendidikan Matematika,Vol 2 (1), pp. 1.

Manurung, D., Siagian, P., and Minarni, A. (2020). The Development of Realistic Mathematics Education Based Learning Tools to Improve Mathematical Problem Solving Ability and Self-Efficacy on Students in Junior High School 1 Lubuk Pakam. Budapest International Research and Critics in Linguistics and Education (BirLE) Journal.Volume 3, No 1, February 2020, Page: 107-118. e-ISSN: 2655-1470 (Online), p-ISSN: 2655-2647.

Marlina, Ikhsan, M \& Yusrizal. (2014). Peningkatan Kemampuan Komunikasi dan SelfEfficacy. Siswa SMP dengan Menggunakan Pendekatan Diskursif. Jurnal Didaktik Matematika. Vol. 1, No. 1, 35-45.

Marliani, N. (2015). Peningkatan Kemampuan Berpikir Kreatif Matematis Siswa Melalui Strategi Pembelajaran Missouri Mathematics Project (MMP). Jurnal Formatif. Vol. 5 (1): $14-25$. 
Marpaung, A. S. (2015). Meningkatkan Kemampuan Pemecahan Masalah dan Self Efficacy Siswa melalui Pendekatan Metakognitif dengan Metode Improve di Kelas X-1 SMA Negeri 1 Lawe Alas. Tesis tidak diterbitkan.Universitas Negeri Medan.

Mukhid, A. (2009). Self-Efficacy: Perspektif Teori Kognitif Sosial dan Implikasinya terhadap Pendidikan. Jurnal Tadrîs (Vol. 4, No. 1). Hlm. 106-122.

Nazwandi.(2010). PMRI (Pembelajaran Matematika Realistik Indonesia) Satu Inovasi dalam Pendidikan Matematika di Indonesia. (Online).

NCTM. (2000). Principles and Standards for School Mathematics. United States of America: The National Council of Teachers of Mathematics, Inc

Ni'mah, A.F., Setiawani, S., and Oktavianingtyas, E. (2017). The Analysis of Mathematic Connection Capability Grade IX A MTs Negeri 1 Jember Subchapter Cube and Block Jurnal Edukasi 2017, IV(1): 30-33

Noviani, J;Syahputra, E \&Murad, A. (2018). The Effect of Realistic Mathematic Education (RME) in Improving Primary School Students' Spatial Ability in Subtopic Two Dimension Shape. Journal of Education and Practice www.iiste.orgISSN 2222-1735 (Paper) ISSN 2222-288X (Online). Vol.8, No.34, 2017.

Nurmayani, L., Doyan, A., and Verawati, N. N. S. P. (2018). Pengaruh Model Pembelajaran Inkuiri Terbimbing terhadap Kemampuan Berpikir Kritis Peserta Didik, Jurnal Pendidikan Fisika dan Teknologi, No. 1, Vol. 4, 98-104. Diaksesdari http://dx.doi.org/10.29303/jpft.v4i1.548.

Nursiddik, I., Noto, M. S., and Hartono, W. (2017). Pengaruh Pembelajaran Matematika Realistik Terhadap Kemampuan Pemahaman Matematis dan Keyakinan Diri Siswa SMP.

Purwanto. (2008). Metodologi Penelitian Kuantitatif. Yogyakarta: PustakaPelajar.

Putria, D. N. (2016). Peningkatan Kemampuan Komunikasi dan Self-Efficacy Matematis Siswa melalui Pendekatan Realistic di SMP N 4 Padangsidimpuan. Tesis tidak diterbitkan. Medan: Program Pascasarjana Unimed.

Ratri, A., Martini, K., and Nugroho, A. (2013). Pembelajaran Kimia dengan Metode Inqury Terbimbing dilengkapi Kegiatan Laboratorium Real dan Virtual pada Pokok Bahasan Pemisahan Campuran. Jurnal Pendidikan Kimia (JPK), 2 (2), 44-49.

Rachmawati, T.E. (2012). Hubungan antara Self-Efficacy dengan Kematangan Karier pada Mahasiswa Tingkat Awal dan Tingkat Akhir di Universitas Surabaya. Jurnal Ilmiah Mahasiswa Universitas Surabaya, 1(1).

Ruspiani. (2000). Kemampuan Siswa dalam Melakukan Koneksi Matematika Tesis Jurusan Matematika. UPI Bandung.

Romli, M. (2016). Profil Koneksi Matematis Siswa Perempuan SMA dengan Kemampuan Matematika Tinggi dalam Menyelesaikan Masalah Matematika. Jurnal Ilmiah Pendidikan Matematika Volume 1 Nomor 2.Hal. 145 - 157.

Russefendi. (1991). Pengantar kepada Membantu Guru Mengembangkan Kompetensinya dalam Mengajar Matematika untuk Meningkatkan CBSA. Bandung: Tarsito.

Rusman. (2012). Model-Model Pembelajaran. Depok : PT Raja Grafindo Persada.

Rusminidan Surya, E. 2017.The Effect of Contextual Learning Approach to Mathematical Connection Ability and Student Self-Confidence Grade VIII SMP Negeri 8 Medan. International Journal of Sciences: Basic and Applied Research (IJSBAR)(2017). Volume 35, No 2, pp 249-262

Safitri, A., Surya, E., Syahputra, E., and Simbolon, M. (2017). Impact of Indonesian Realistic Mathematics Approach to Students Mathematic Disposition on Chapter Two Composition Function and Invers Function in Grade XI IA-1 SMA Negeri 4 
Padangsidimpuan. International Journal of Novel Research in Education and Learning Vol. 4, Issue 2, pp: (93-100), Month: March - April 2017. ISSN 2394-9686.

Saminanto and Kartono. (2015). Analysis of Mathematical Connection Ability in Linear Equation with One variable Based on Connectivity Theory. International Journal of Educationand Research, Vol. 3 No. 4, hlm.259-270.

Sanjaya, W. 2006. Strategi Pembelajaran. Jakarta: Kencana Prenada Media Group.

Sanjaya, W. 2010. Strategi Pembelajaran Berorientasi Standar Proses Pendidikan. Jakarta: Kencana.

Santrock, J. W. (2007). Adolescence Perkembangan Remaja. Jakarta: Erlangga

Saragih, S. (2007). Mengembangkan Kemampuan Berpikir Logis dan Komunikasi Matematik Siswa Sekolah Menengah Pertama Melalui Pendekatan Matematika Realistik.Disertasi Doktor Tidak diterbitkan. UPI: PPS UPI.

Sari, D.P., Syahputra, E. and Surya, E. (2018). An Analysis of Spatial Ability and Selfefficacy of Students in Cooperative Learning by Using Jigsaw at Smas Muhammadiyah 8 Kisaran. American Journal of Educational Research, 2018, Vol. 6, No. 8, 1238-1244 Available online at http://pubs.sciepub.com/education/6/8/25. CScience and Education Publishing. DOI:10.12691/education-6-8-25.

Schunk, D.H. 1995. Self-Efficacy, Motivation and Performance.Journal of Applied Sport Psychology.

Shofiah, V \& Raudatussalamah. (2014). Self-Efficacy dan Self-Regulation sebagai Unsur yang Penting dalam Pendidikan Berkarakter (Aplikasi Pembelajaran Mata Kuliah Akhlak Tasawuf).Kutub Khanah: Jurnal Penelitian Social Keagamaan. Vol. 17, No. 2, 214-229

Siagian, M.D. (2016). Kemampuan Koneksi Matematik dalam Pembelajaran Matematika.MES (Journal of Mathematics Education and Science). Vol. 2, No. 1, 6758.

Simanungkalit, R.H. (2015). Pengembangan Perangkat Pembelajaran untuk Meningkatkan Kemampuan Representasi Matematis dan Self-Efficacy siswa SMP Negeri 12 Pematang Siantar.Tesis tidak diterbitkan. Medan: PPs Unimed

Sinaga, Y. F. (2014). Peningkatan Kemampuan Berpikir Kritis dan Self-Efficacy Matematis Siswa SMP dengan Pendekatan Pembelajaran Savi Berbantuan Wingeom.Tesis tidak diterbitkan. Medan : Program Pasca Sarjana Unimed.

Sipahutar, A. M., Sinaga, B., and Syaputra, E. (2019).Difference of Critical Thinking Ability and Ability to Solve Mathematical Problem Students of SMP Negeri 3 Sibabangun using Metacognitive Learning Model and Inquiry. Advances in Social Science, Education and Humanities Research, 4th Annual International Seminar on Transformative Education and Educational Leadership (AISTEEL 2019).

Siregar, A. S., Surya, E., Syahputra, E., and Sirait, A.R. (2018). The Improving Mathematical Communication Ability and Students' Self-Regulation Learning through Realistic Mathematical Approach Based on Batak Toba Culture. American Journal of Educational Research, 2018, Vol. 6, No. 10, 1397-1402 Available online at http://pubs.sciepub.com/education/6/10/9. OScience and Education Publishing DOI:10.12691/education-6-10-9.

Skaalvik, E.M., Federici, R.A. and Klassen, R.M. (2015). Mathematics Achievement and Self-Efficacy: Relations with Motivation for Mathematics. International Journal of Educational Research. Vol. 72, 129-136.

Sofa. (2008). Pendekatan Pembelajaran Matematika Realistik. Online (http://www.nizland. Cari Ilmu Online Borneo.htm wordpress.com/). Diakses 19 September 2019.

Sugiyono (2015). Metode Penelitian Kombinasi (Mix Methods). Bandung: Alfabeta. 
Sukoco, H. \& Mahmudi, A. (2016). Pengaruh Pendekatan Brain-Based Learning terhadap Kemampuan Komunikasi Matematis dan Self-Efficacy Siswa SMA. Phytagoras: Jurnal Pendidikan Matematika.Vol.11, No, 1. 11-24.

Sumarmo, U. (2010). Berpikir dan Disposisi Matemati: Apa, Mengapa, dan Bagaimana Dikembangkan pada Peserta Didik [Online]

Surya, E., Putri, F. A., \& Mukhtar. (2017). Improving Mathematical Problem-Solving Ability and Self-Confidence of High School Students through Contextual Learning Model.Journal on Mathematics Education.Vol. 8 No. 1.Pp: 85-94.

Susanti. (2017). Meningkatkan Kemampuan Pemecahan Masalah Matematis dan SelfEfficacy Siswa MTs melalui Pendekatan Pendidikan Matematika Realistik. Suska Journal of Mathematics Education. (p-ISSN: 2477-4758|e-ISSN: 2540-9670). Vol. 3, No. 2, 2017, Hal. 92 - 101.

Syahputra, E. (2016). Statistika Terapan untuk Quasi dan Eksperiment di Bidang Pendidikan, Biologi, Pertanian, Teknik, dll. UNIMED Press: Medan.

The National Council of Teachers of Mathematics (NCTM). (2000). Principles and Standards for School Mathematics Reston,VA: NCTM.

Trianto, (2007). Model-Model Pembelajaran Inovatif Berorientasi Kontruktivistik. Prestasi Pustaka: Jakarta.

Trianto (2009). Mendesain Model Pembelajaran Inovatif Progresif.Surabaya:Kencana.

Turmudi.(2001). Implementasi Awal Pembelajaran Matematika dengan Pendekatan Matematik Realistik Di SLTP Negeri 2 Bandung.Makalah Seminar Nasional Pendidikan MIPA di FMIPA UPI Bandung.

Turmudi,dkk.(2003). Strategi Pembelajaran Matematika Kontemporer. Bandung: Univ. Pendidikan Indonesia.

Wahyuni, S., and Arisa. (2018). Efektifitas Model Pembelajaran Inquiry Based Learning dalam Meningkatkan Pembelajaran Bahasa Indonesia Siswa SMP Kecamatan Sabbangparu. Jurnal KIBASP (Kajian Bahasa, Sastra dan Pengajaran). Volume 1, Nomor 2, Juni 2018 e-ISSN: 2597-5218. p-ISSN: 2597-520X. DOI: https://doi.org/10.31539/kibasp.v1 i2.225.

Wijaya, A. (2012). Pendidikan Matematika Realistik, Suatu Alternatif Pendekatan Pembelajaran Matematika . Yogyakarta: Graha Ilmu. 